\title{
Bagasse-based co-generation at Hippo Valley Estates sugar factory in Zimbabwe
}

\section{Busiso Mtunzi \\ Ntshengedzeni Mampwheli}

Edson Meyer

Institute of Technology, University of Fort Hare, South Africa

\section{Wilson Mungwena}

Department of Physics, University of Zimbabwe, Zimbabwe

\begin{abstract}
The paper reports on the assessment of the use of bagasse for cogeneration purposes at Hippo Valley Estates (HVE), a sugar manufacturing company in Zimbabwe. Much emphasis was on an assessment of the quantity of energy that was lost due to inefficient combustion of bagasse and the use of steam that was generated. The study investigated the quantity of sugar cane processed and the possible corresponding steam produced; the sugarcane processed was found to be approximately $2.33 \mathrm{mil}-$ lion tons per annum and the steam produced was 193.1 tons per hour. The steam was used in the process department as well as to drive mills. The excess steam generated was found to be 81.03 tons per hour. Economic analysis on the use of excess steam to produce extra power for sale to the utility company was also undertaken. It was established that the power plant for the company could generate an annual surplus of US2.8Million as revenue, and the payback period was found to be 3.3 years. The sensitivity analysis of the project indicated that the electricity prices as well as the energy produced were the most sensitive areas in the project. The other inputs such as operations and maintenance costs, interest, capital investment and number of years were not as sensitive as the price and the energy.
\end{abstract}

Key words: bagasse; co-generation, steam, de-super heaters

\section{Introduction}

Sugarcane bagasse is a carbonaceous waste resulting from the processing of sugarcane mainly in sugar manufacturing processes. This bagasse is usually combusted as in boilers to generate steam for downstream processes, this result in the combined use of managing the waste and utilization of bagasse as fuel. The utilization of the heat potential of the bagasse waste is essential to economic production of sugar. If other fuels such as coal are used without the bagasse waste, this would substantially increase the cost of sugar production.

Cogeneration and grid connection would certainly be of much help in Zimbabwe if stronger linkages exist between sugar companies and the utility company. Such linkages have been found to work in Mauritius where 10 out of 11 sugar factories are exporting electricity during crop season and this has been seen to assist the utility in terms of meeting the electricity demand for the country (Deepchand, 2000). Electrical energy from Zimbabwe's power station has been found to be about 7090GWh per annum, which represents approximately $65 \%$ of the country's annual demand, which is approximately $12500 G W h$. The balance of approximately $33 \%$ is supported by from imports (Mangwengwende, 2002). If the two sugar factories, (Triangle Limited and Hippo Valley Estates) are to feed into the grid, then the deficit may be reduced helping the country to reduce its electricity importation bill. This study sought to establish the technical and economic aspects as well as the power that HVE could export. The study also intended to estimate the price at which it could sell its electricity to Zimbabwe Electricity Supply Authority (ZESA). This study 
arose out of the need for the economic independent power producers supplying electricity to the Grid (DOE, 2002). Such power producers were meant to support future growth and development in Zimbabwe. The results of this study could then be used by other environmentally conscious companies and institutions.

\section{Bagasse production and use at Hippo Valley Estates}

The sugar cane is one of the most efficient converters of the solar energy into biomass via photosynthesis. The major components of the sugar cane are the sugar fraction and the fibre fraction, the latter being bagasse. The bagasse produces thermal energy on combustion and gives off carbon dioxide as a by-product, but carbon dioxide produced is then absorbed by the next generation of cane making the process carbon neutral. It should be noted that 1 ton of coal produces 3.02 tonnes of carbon dioxide (Deepchand, 2000), and the burning of coal is not carbon neutral. The use of bagasse would reduce the carbon emissions.

This research project was carried out to assess the use of bagasse in cogeneration at HVE, as well as to provide the company and other sugar manufacturing companies with economic knowledge on bagasse based cogeneration. HVE has been co generating steam and electricity for their site specific consumption since the company started operating in 1959. The company currently processes 2.33 million tons of sugar cane annually to get at least 270000.00 tonnes of sugar.

Electrical production is another possible source of revenue the company could exploit through selling electricity using its excess electrical generating capacity in the form of excess fuel (bagasse), which is currently incinerated inefficiently in the boiler. The efficient use of bagasse could generate more electrical energy that could result in excess electricity, which in turn could be sold to the utility company. The utility company is currently unable to meet the country's electricity demand.

The quantity of bagasse produced was found to average $27.5 \%$ by weight of cane crushed implying that $275 \mathrm{~kg}$ of bagasse was produced per ton of sugar cane. HVE processes 2.33 Million tonnes of sugar cane yearly resulting in the production of 640 750 tonnes of bagasse annually. Using this bagasse, the company currently generates $13.5 \mathrm{MW}$ of electricity for each crushing period but they have the potential to double the generation capacity.

\section{Zimbabwe's yearly electricity import}

Table 1 illustrates the yearly electricity import for Zimbabwe from the year 2000 to 2009. The table was included show the electricity shortage in the country and the need to find ways of increasing the generation capacity.

Table 1: Yearly electricity import in Zimbabwe (Electricity import information, 2011)

\begin{tabular}{lcc}
\hline Year & $\begin{array}{c}\text { Yearly import } \\
\text { (million kWh) }\end{array}$ & $\begin{array}{c}\text { Av. monthly import } \\
\text { (million kWh) }\end{array}$ \\
\hline 2000 & 1921 & 160.08 \\
\hline 2001 & 1564 & 130.33 \\
\hline 2002 & 4500 & 375.00 \\
\hline 2003 & 3550 & 295.83 \\
\hline 2004 & 3550 & 295.83 \\
\hline 2005 & 3000 & 250.00 \\
\hline 2006 & 3300 & 275.00 \\
\hline 2007 & 2250 & 187.50 \\
\hline 2008 & 2867 & 238.92 \\
\hline 2009 & 2867 & 238.92 \\
\hline
\end{tabular}

It is clear from Table 1 that there is a need for additional power generation capacity in the country to meet the demands currently met through the electricity imports. The feed in from the sugar manufacturing companies would meet the deficit and help the utility company to reduce its imports.

\section{Technological description of the plant at HVE}

The power plant has generating stations driven by steam. The steam is produced by both bagasse and coal fired boilers. There are six high pressure (3.1MPa) John Thompson Water Tube type boilers in use at HVE. Their final steam temperature was $400^{\circ} \mathrm{C}$ and Table 2 gives the description of the boilers.

Table 2: John Thompson boilers at HVE fuelled by coal and bagasse

\begin{tabular}{lcccc}
\hline Boiler no. & Fuel type & Steam temperature $\left({ }^{\circ} \mathrm{C}\right)$ & Pressure $(\mathrm{MPa})$ & Max. continuous rating (ton/hr) \\
\hline 1 & Coal and bagasse & 400 & 3.1 & 45 \\
\hline 2 & Coal and bagasse & 400 & 3.1 & 45 \\
\hline 3 & Coal and bagasse & 400 & 3.1 & 45 \\
\hline 4 & Bagasse & 400 & 3.1 & 100 \\
\hline 5 & Bagasse & 400 & 3.1 & 68 \\
\hline 6 & Bagasse & 400 & 3.1 & 68 \\
\hline
\end{tabular}




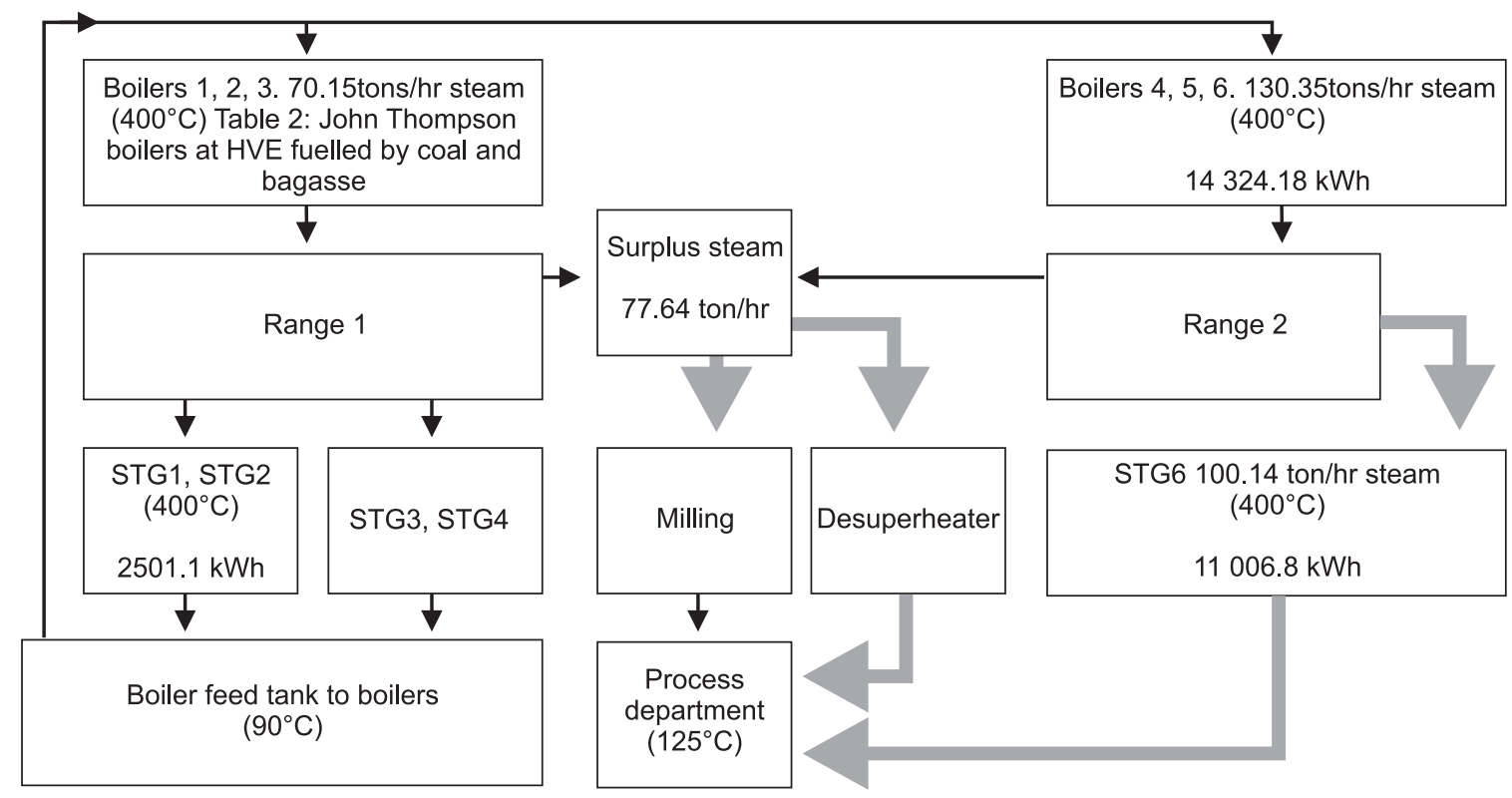

Figure 1: Flow diagram of the high pressure steam

If all boilers were operating at maximum continuous rating their output would be $371 \mathrm{t} / \mathrm{hr}$ of steam. However, they were generating $200.45 \mathrm{t} / \mathrm{hr}$ of team, which implies that they were operating at $54 \%$ capacity. Boiler 1, 2 and 3 have a combined rating of 135 ton/hr steam production and they were producing 70.1 tons $/ \mathrm{hr}$ of steam implying that they were operating at $52 \%$ capacity. The other boilers 4, 5 and 6 have a combined rating of $236 \mathrm{ton} / \mathrm{hr}$ steam production but they were producing $130.35 \mathrm{t} / \mathrm{hr}$ of steam, which implies that they were operating at $55 \%$ capacity. The first three boilers have a travelling grate for dumping ashes after the fuel has been burnt. Boilers 4, 5, and 6 are fuelled by bagasse and these boilers have dump grates for dumping ashes.

Figure 1 shows the flow diagram of the high pressure steam. The steam produced from the boilers is directed to steam headers and then into the main range for further distribution.

The steam turbines (STG1, STG 2, STG 3, and STG4) are condensing steam turbine generator sets. Their condensates at a temperature of about $100^{\circ} \mathrm{C}$ are supplied to the boiler feed tank together with the condensates from the process department. The water from the water treatment plant is also added to cater for the water lost as vapour.

\section{Methodology}

The daily plant reports were chosen as the main tool of data collection. The reports contain quantitative data. Daily plant reports for the months of July and August were analysed and then only days which had crushing rates of more than 10000 tonnes of sugar cane were then sampled.

Load cells were used for weighing sugar cane.
Records for the steam production, steam temperature, rate of steam flow from the boilers, power generation output from turbines as well as steam supply to the process departments were collected. All these records were filed and obtained from the power plant department and the company's laboratory. The laboratory compiles information from the power plant and that from other departments such as milling for the efficient management of the process and plant energy demand. The data collected was then used to determine the average steam produced per day on hourly basis.

\subsection{Steam consumption by steam turbines}

The steam consumption of the steam turbines was determined as follows:

$$
Q=\frac{860}{\left(\lambda-\lambda^{1}\right) * \mu \rho_{m} \rho_{r} \rho_{g}}
$$

$Q=$ Steam consumption of the turbo - alternator set, in $\mathrm{kg} / \mathrm{kWh}$

$\lambda=$ total heat of the steam at the nozzle chest, in $\mathrm{kcal} / \mathrm{kg}$

$\lambda^{1}=$ total heat of the exhaust steam, in $\mathrm{kcal} / \mathrm{kg}$

$\eta=$ thermodynamic efficiency of the turbine

$\rho_{m}=$ mechanical efficiency of the turbine

$\rho_{r}=$ efficiency of the reduction gear

$\rho_{g}=$ efficiency of the generator or alternator

$\rho_{g}$ varies with power $0.94-0.985$.

$\rho_{r}$ varies from 0.97 to 0.985 .

$\eta$, thermodynamic efficiency of the turbine (Hugot, 1986), which depends on:

- The mechanical standard of construction

- Its power; the more powerful the turbine the higher the efficiency

- The adiabatic heat drop; the higher the 
drop the better the efficiency (Yunus et al, 1994).

The steam consumption losses through condensation and losses by leaks were determined from the following relationships:

- Losses through condensation range, which is 3$5 \%$

- Losses by leaks range, which is $2-3 \%$

The data used to calculate the steam consumption rate of the steam turbines is presented in Table 3.

Table 3: The data used to calculate the steam consumption rate

\begin{tabular}{|c|c|}
\hline Parameter & Value \\
\hline Inlet temperature & $400^{\circ} \mathrm{C}$ \\
\hline Outlet temperature & $125^{\circ} \mathrm{C}$ \\
\hline Inlet pressure & $3.1 \mathrm{MPa}$ \\
\hline Outlet pressure & $0.14 \mathrm{Mpa}$ \\
\hline $\begin{array}{l}\text { The total heat of steam at the nozzle } \\
\text { chest from linear interpolation }\end{array}$ & $3229.3 \mathrm{~kJ} / \mathrm{kg}$ \\
\hline Total heat of the exhaust steam $\lambda^{1}$ & $2690.0 \mathrm{~kJ} / \mathrm{kg}$ \\
\hline $\begin{array}{l}\text { The thermodynamic efficiency of the } \\
\text { turbine }(\eta)\end{array}$ & 0.81 \\
\hline Mechanical efficiency of the turbine $\left(\rho_{m}\right)$ & 0.985 \\
\hline $\begin{array}{l}\text { Efficiency of the reduction gearing, if it } \\
\mathrm{s} \text { a geared turbine }\left(\rho_{\mathrm{r}}\right)\end{array}$ & 0.980 \\
\hline
\end{tabular}

\subsection{Analysis of bagasse and coal used}

\subsubsection{Bagasse}

The ultimate analysis as well as the proximate analysis of bagasse was undertaken. The proximate analysis defines the magnitude of the ash, moisture, volatiles, fixed carbon; while the ultimate analysis defines the composition of carbon, hydrogen, nitrogen, oxygen and sulphur.

The Gross Calorific Value (GCV) and Net Calorific Value (NCV) on wet basis were determined using the following equations:

$$
\begin{aligned}
& G C V_{w}=4600(1-W)-1200 S \\
& N C V_{w}=42501-485 W-1200 S
\end{aligned}
$$

Where $\mathrm{W}$ is the water content in bagasse $(48 \%)$ and $\mathrm{S}$ is the sugar content in bagasse $(4 \%)$ (Hugot, 1986).

The quantity of heat remaining to be transferred to the steam is therefore given as:

$$
\begin{aligned}
M_{v} & =[4250-4850 W-1200 S-q]^{*} \alpha \beta \eta \\
& =[N C V-q]^{*} \alpha \beta \eta
\end{aligned}
$$

The coefficients are $\alpha, \beta, \eta$ where $\alpha$ is the coefficient taking into account the losses due to incom- plete combustion, $\beta$ is the coefficient taking into account the losses due to radiation and $\eta$ is the coefficient taking into account the losses due to unburnt solids.

$M_{v}$ is the heat transferred to the steam per $\mathrm{kg}$ of bagasse burnt in $\mathrm{kJ} / \mathrm{kg}, \mathrm{W}$ is moisture of bagasse, $\mathrm{S}$ is the sugar content per kilogram of bagasse and $\mathrm{q}$ is the sensible heat loss of flue gases.

$\alpha=0.98$ for ordinary furnaces and $\alpha=0.975$ for Spreader stoker furnaces (Hugot, 1986). The Spreader Stocker furnaces are the type of furnaces in use at HVE, $\beta=0.975$ and $\eta=0.965$. The sensible heat loss $(q)$ was found to be $1.43 \mathrm{MJ} / \mathrm{kg}$. The sensible heat loss was determined as follows:

$$
q=[(1-W)(1.4 m-0.13)+0.5]^{* t}
$$

Where $q$ is the sensible heat loss in $\mathrm{kcal} / \mathrm{kg}, W$ is the moisture content in the bagasse (48\%), $m$ is the excess air ratio (1.4) and $t$ is the flue gas temperature $\left(235^{\circ} \mathrm{C}\right)$.

The quantity of heat transferred to the steam, $M_{v}$ was found to be $5.89 \mathrm{MJ} / \mathrm{kg}$. The heat required to produce a kilogram of high pressure steam at HVE can be obtained from the steam tables. The boilers produced the steam at 3.1Mpa. At this pressure the corresponding enthalpy $\left(\mathrm{h}_{\mathrm{g}}\right)$ was found to be $3.23 \mathrm{MJ} / \mathrm{kg}$. Boiler feed-water was supplied at $90^{\circ} \mathrm{C}$ implying a feed-water enthalpy $\left(\mathrm{h}_{\mathrm{f}}\right)$ of $0.377 \mathrm{MJ} / \mathrm{kg}$. The difference between the two gave the heat added to water $(2.85 \mathrm{MJ} / \mathrm{kg})$.

$1 \mathrm{~kg}$ of steam requires $2.85 \mathrm{MJ}$ from the bagasse and $1 \mathrm{~kg}$ of bagasse produces $5.89 \mathrm{MJ}$

Therefore, $1 \mathrm{~kg}$ of bagasse can produce steam of weight given by:

$$
\sigma=5.89 / 2.85=2.07 \mathrm{~kg}
$$

\subsubsection{Coal}

Coal is always used in coal fired boilers to cater for the downtime. Equations 3 and 4 were applied to determine the amount of steam produced by a kilogram of coal and it was found to be $7.33 \mathrm{~kg}$ of steam.

\section{Economic evaluation}

Different frameworks and methods of pricing by co generating companies are available and these can be adopted by sugar manufacturing companies. These are detailed below.

\subsection{Pricing of power sales by co-generators}

There are several types of power transactions that can arise in the context of a market for excess power supply from the co-generators. The following transactions can be followed out or used:

Direct sale to the grid: In this transaction a cogenerating sugar mill will be selling its excess power to the utility company, for example, ZESA. The sell- 
ing price would be a contractually agreed price.

Wheeling: In this transaction the utility company will be there to transmit (wheel) the co generated power for simultaneous delivery to another location. This could be a sister company or to a third party. In this, the utility company charges a transmission (wheeling) fee. Whereas the final purchaser of electricity pays the sugar mill directly for the power at the agreed price.

Banking: This transaction involves a co-generator selling its excess power to ZESA for withdrawal for its use at a later time.

Banking plus wheeling: In this transaction a utility company pays back the banked energy by wheeling the power to a delivery point different from the point of injection. This delivery could be to a sister company of the sugar mill or to a third party.

Power purchase tariffs for direct sales to the grid are the ones of concern. Direct sales to the grid comprise over $99 \%$ of transactions in established power markets worldwide.

The economic cost of generating and supplying electricity and therefore the value of the grid of any purchases vary by time of the day due to demand variations.

\subsection{Avoided cost}

The value of power generated by independent power producers (IPPs) is given by a utility company as the avoided cost from the perspective of the utility. These are the costs of generation, transmission and distribution, as well as fuel, which the utility company (ZESA) no longer needs to incur by virtue of the operation of the independent source.

The avoided energy cost is usually given by the utility company. However this cost has to be compared to the generation cost of a company.

\subsection{Power generation cost}

Since a No cost waste product is used as a fuel and co-generation requires little or no additional labour at the mill. The labour cost is already accommodated in the operations of the company. A large element of the cost of co-generation involves the initial capital investment. The economic viability is highly sensitive to the amount of power exported per unit of capital investment as would be shown on the sensitivity analysis.

\subsection{Capital \& operating cost estimates}

A 20MW pass out steam turbine purchased in 2001 was US\$5 200 000. This was considered in carrying out the economic evaluation of the project. The cost of piping, civil, electrical, foundation work, building, water cooling, and instrumentation were taken from actual projects elsewhere such as Honduras for a similar size of the steam turbine (WIIAD, 1994). The total estimated capital costs included $20 \%$ for miscellaneous items and for contingency.
In an economy with market annual interest rate of $\mathrm{i}$ and an average annual inflation $\mathrm{f}$, the discount rate is given by the following:

$$
r=\left[\frac{(1-i)}{(1+f)}\right]-1
$$

It can be observed that the real discount rate is therefore not $i$ (Doing business in the USA general information, 2002).

The discount rate used in all the economic analysis in this study will be assumed using the United States of America market interest rate (i), which is $6.75 \%$ and inflation rate $(\mathrm{f})$, which is $3.2 \%$.

For the analysis, the uniform series present worth was used and is given by (Renschhausen, 2001).

$$
P / A(I, n))=\frac{\left[A *(1+I)^{n}-1\right]}{\left[I *(1+I)^{n}\right]}
$$

Where $\mathrm{P} / \mathrm{A}$ is the present worth of the investment, I is the interests and $n$ is the number of years.

Table 4 shows the capital and operating estimates used to determine the costs applied during the determination of the net present value of the investment as well as the payback period.

\begin{tabular}{|c|c|}
\hline Power & $20 \mathrm{MW}$ \\
\hline Steam turbines SG6 (20MW) & US\$5 200000.00 \\
\hline Erection and engineering & US\$4 446875.00 \\
\hline Subtotal & US\$9 646875.00 \\
\hline $\begin{array}{l}\text { Contingency and miscellaneous } \\
\text { at } 20 \%\end{array}$ & US\$1929375.00 \\
\hline Total cost of investment $\left(\mathbf{I}_{\mathbf{o}}\right)$ & US\$11 576250.00 \\
\hline Life & 25 years \\
\hline $\begin{array}{l}\text { Operational and maintenance } \\
\left.\text { cost/yr @ 3\%(I } \mathbf{I}_{\mathbf{o}}\right)\end{array}$ & US\$ 347287.50 \\
\hline Interest rate & $3.44 \%$ \\
\hline Revenue per kWh & US\$0.056 \\
\hline Available energy per year & 69 510.72MWh \\
\hline
\end{tabular}

Table 4: Capital and operating estimates

\section{Results and discussion \\ 7.1 Ultimate and proximate analysis of bagasse and coal}

Table 5 overleaf shows the proximate and ultimate analysis of bagasse. The moisture content of the bagasse was found to be $48 \%$ and the Gross Calorific Value was found to be $9.81 \mathrm{MJ} / \mathrm{kg}$ while the Net Calorific Value was $7.85 \mathrm{MJ} / \mathrm{kg}$. However, it was found that not all of this heat from the bagasse goes into steam production. There are also heat losses taking place in the furnace as well as in the boiler. The losses consist of the following:

- Latent heat of water formed by combustion of 
Table 5: Proximate and ultimate analysis of bagasse

\begin{tabular}{lc}
\hline Proximate analysis & Composition (\%) \\
\hline Fixed carbon & 11.82 \\
\hline Volatile Matter & 84.79 \\
\hline Ash & 2.91 \\
\hline Moisture & 48 \\
\hline Total & 100 \\
\hline Ultimate analysis & \\
\hline Carbon & 49.2 \\
\hline Hydrogen & 4.69 \\
\hline Oxygen & 43 \\
\hline Nitrogen & 0.18 \\
\hline Sulphur & 0.02 \\
\hline Other Elements & 2.43 \\
\hline Gross calorific value & $9.81 \mathrm{MJ} / \mathrm{kg}$
\end{tabular}

hydrogen found in the bagasse

- Latent heat of water contained in the bagasse

- Sensible heat of the flue gas leaving the boiler

- Losses of heat in ash and grit

- Losses of heat by radiation and convection from the furnace and boiler

- Losses due to incomplete combustion of carbon giving carbon monoxide instead of Carbon dioxide

The $7.85 \mathrm{MJ} / \mathrm{kg}$ already takes into consideration the losses due to the first and second points. The other losses are taken into account by means of coefficients applied to the total quantity of heat, 9.81MJ/kg.

Table 6 shows the ultimate and proximate analysis of coal. The NCV for coal was found to be $23.04 \mathrm{MJ} / \mathrm{kg}$ and the total sensible heat loss was found to be $2.15 \mathrm{MJ} / \mathrm{kg}$ resulting in $21.07 \mathrm{MJ} / \mathrm{kg}$ of the heat transferred to steam.

Table 6: The ultimate and proximate analysis of coal

\begin{tabular}{lc}
\hline Ultimate analysis & Composition (\%) \\
\hline Carbon & 63.4 \\
\hline Hydrogen & 3.50 \\
\hline Sulphur & 1.30 \\
\hline Nitrogen & 1.60 \\
\hline Oxygen & 5.70 \\
\hline Other elements & 4.2 \\
\hline Proximate analysis & 29.4 \\
\hline Fixed carbon & 32.3 \\
\hline Volatile matter & 16.5 \\
\hline Ash & 8.00 \\
\hline Moisture & $700-800$ \\
\hline Bulk density $\left(\mathrm{kg} / \mathrm{m}^{3}\right)$ & 26.7 \\
\hline Gross calorific value $(\mathrm{MJ} / \mathrm{kg})$ & 23.04 \\
\hline Nett calorific value $(\mathrm{MJ} / \mathrm{kg})$ &
\end{tabular}

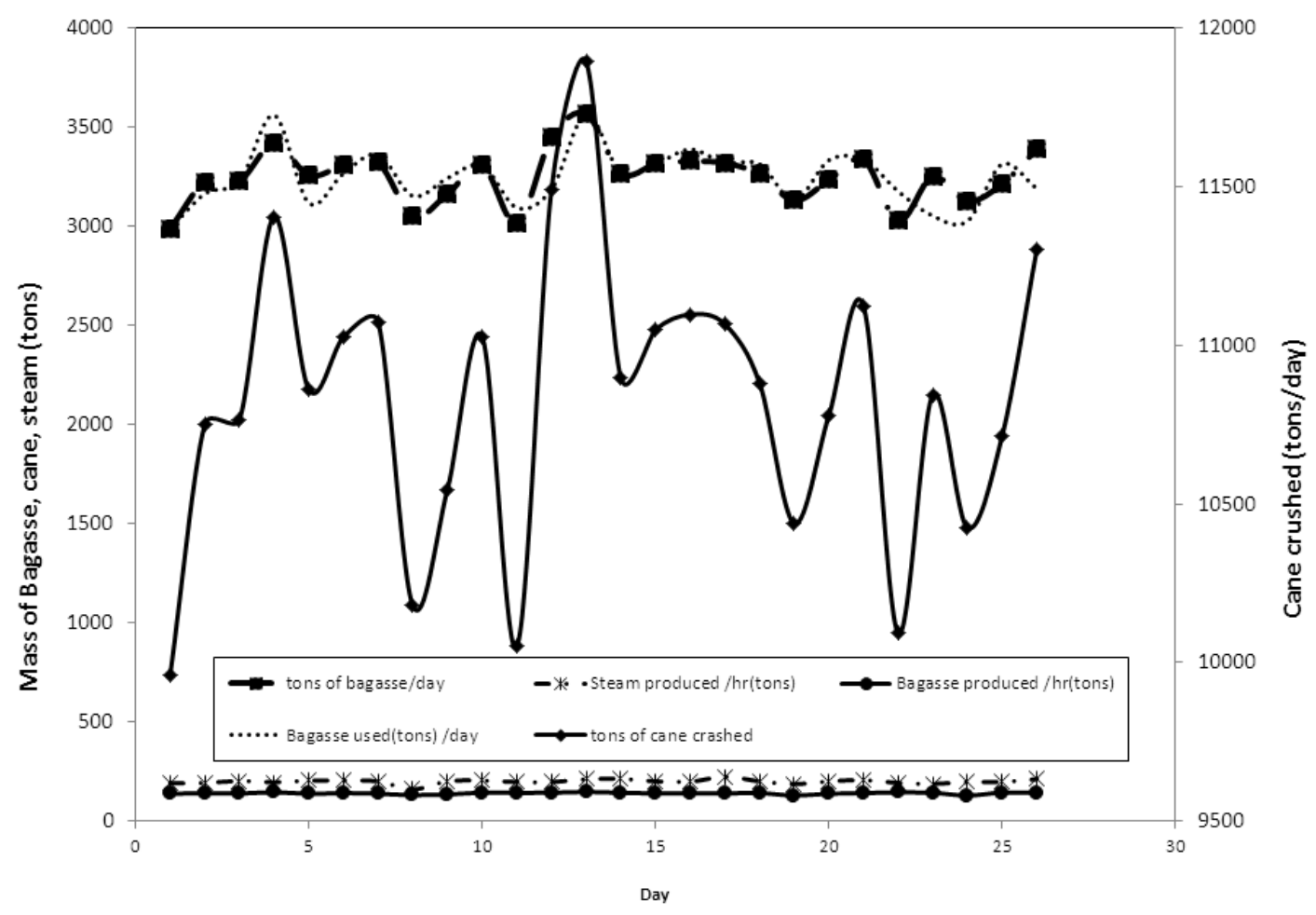

Figure 2: The quantity of sugarcane crushed, bagasse produced, bagasse used as well as steam produced 


\subsection{Bagasse and steam production}

The average steam produced per day was found to be 193.11tons/hr. On average, the excess bagasse stored in the bagasse store was found to be 470 tons/day and the crushing rate averaged 10836 tons/day of cane sugar.

There were six steam turbines sets at HVE but during the investigations only two were in operation - these were STG6 rated at $20 \mathrm{MW}$ and STG2 rated at 5 MW. STG2 could do both pass out or condensing. The two could meet the plant and the estate's electrical requirements, which was 13.5 MW. Table 7 presents the steam consumption rates by steam turbines.

The steam consumption by prime movers, which are shredders, de-watering mills, drying off mills and steam feed pumps was found to be 77.53tons/hr. The total steam requirement for the plant was therefore 200.43 tons/hr. Table 8 shows the excess steam and excess bagasse produced.

The bagasse used was found to be 130.30 tons/hr and this quantity of bagasse was capable of producing 267.92 ton/hr of steam. This implied an excess steam of 69.3 tons/hr that could be produced. The total average hourly bagasse storage was found to be 18.86 tons, and adding this to hourly stored bagasse resulted in an excess storage capacity of 52.33 tons/hr of bagasse. The excess steam could add value through generation of additional electricity. Since there are 244 days for crushing the cane per year, it therefore implies that the quantity of bagasse in excess was 306444 tons per year and this could be used more efficiently to generate excess electricity. If this extra bagasse is used this would translate to an additional generating potential of 69510.72 MWh per year.

The steam consumption rate was found to be $8.67 \mathrm{~kg} / \mathrm{kWh}$ without considering the heat loss. Adding heat loss of $5 \%$ then the steam consumption rate was found to be $9.104 \mathrm{~kg} / \mathrm{kWh}$. Considering STG6, which produces $11 \mathrm{MW}$ at steam consumption rate of $100.144 \mathrm{t} / \mathrm{h}$, then excess steam of 69.3tons/hr, would be capable of producing in excess power of 7.61MW.

It has been established that $1 \mathrm{~kg}$ of bagasse produces $2.064 \mathrm{~kg}$ of steam, and bagasse stored was 18.86tons/h, implying a potential of $38.93 \mathrm{tons} / \mathrm{hr}$ excess steam. This excess steam could be used to generate $4.26 \mathrm{MW}$ of electricity. Therefore, using bagasse alone the potential power output from the plant could total 25.37MW. Hence the company could sell an excess of $11.87 \mathrm{MW}$. The maximum capacity of the company was found to be 33MW. At $25.37 \mathrm{MW}$ the plant could be operating at $75 \%$ capacity.

\subsection{Economic evaluation}

The discount rate was found to be $3.44 \%$. A revenue of $Z \$ 3.06$ which then translated to $0.056 \mathrm{US} \$ / \mathrm{kWh}$ in 2002 was used and this was the domestic tariff charge from ZESA for a customer using electricity in the range of $51-300 \mathrm{kWh}$ and this happened to give the least expected price (Nyatanga, 2002). ZESA, the national power utility in Zimbabwe, is the sole producer and trader of electricity. Mangwngwende (2002) also averaged the electricity tariff at $4.9 \mathrm{USc} / \mathrm{kWh}$ and this was within the range used for the economic calculations.

The NPV of the investment indicated that the investment was feasible. The cost to the company per $\mathrm{kWh}$ generated was found to be US $\$ 0.0151$ and the payback period was found to be 3.3years. The sensitivity analysis of the investment was undertaken and the results showed that the project was more sensitive to price changes as well as to energy output changes.

\section{Conclusion and recommendations}

The paper examined the possibility of Hippo Valley Estate generating electricity using excess bagasse in order to sell to the utility company (ZESA) for revenue generation. It was established that 69.3 tons/hr of steam was lost either through inefficient burning of bagasse or through venting off of steam

Table 7: Steam consumption by steam turbines

\begin{tabular}{lcccc}
\hline Type of turbine & $\begin{array}{c}\text { Rated power } \\
(\mathrm{MW})\end{array}$ & $\begin{array}{c}\text { Rated steam consumption } \\
\text { (tons/hr) }\end{array}$ & $\begin{array}{c}\text { Actual power output } \\
(\mathrm{MW})\end{array}$ & $\begin{array}{c}\text { Steam consumption } \\
\text { (tons/hr) }\end{array}$ \\
\hline STG2 Pass out/condensing & 5.00 & 45.52 & 2.50 & 22.76 \\
\hline STG5 Pass Out & 8.00 & 72.83 & 0.00 & 0.00 \\
\hline STG6 Pass out & 20.00 & 182.08 & 11.00 & 100.14 \\
\hline Total & 33.00 & 300.43 & 13.5 & 122.90 \\
\hline
\end{tabular}

Table 8: Excess bagasse and steam (tons/hr)

\begin{tabular}{lccccc}
\hline Bagasse used & $\begin{array}{c}\text { Steam } \\
\text { production }\end{array}$ & $\begin{array}{c}\text { Steam } \\
\text { consumption }\end{array}$ & Excess steam & Excess bagasse & $\begin{array}{c}\text { Excess stored } \\
\text { bagasse }\end{array}$ \\
\hline 130.30 & 267.92 & 200.43 & 69.3 & 33.47 & 52.33 \\
\hline
\end{tabular}


through valves on the boilers or through the main range. It was also established that if inefficient use of bagasse and venting of steam is stopped this would imply a realization of power equivalent to 7.61MW.

The plant was found to operate under conditions where excess bagasse caused operational problems of storage and handling and as a result bagasse was burnt inefficiently. If steam turbines were to be operated optimally then the bagasse that is normally stored on a daily basis would then be used to produce an extra power of $4.26 \mathrm{MW}$. The resulting possible power output was found to be 11.87MW. This translated to 69,510.72MWh per year. The company was found to be able to collect revenue of about US\$3.9Million per year from the utility company ZESA. For profitable co-generation the price greater than a generation cost of US\$0.0151/kWh was recommended.

It was also recommended that the condensing equipment should be built to condense the excess steam. The condensed steam would give a condensate which would be free from impurities. The sensitivity analysis of the project showed that the electricity prices as well as the energy produced were the most sensitive areas in this project. The other inputs such as operations and maintenance costs, interest, capital investment and number of years were not as sensitive as the price and energy.

\section{References}

Deepchand, K. (2000). Bagasse energy development the Mauritian Experience, International Sugar Journal, 2000, Vol. 102, No. 1215: 127-138.

Department of Energy (DOE) (2000). Electricity White Paper; Electricity Sector Reform in Zimbabwe. Government report. Zimbabwe.

Hugot E. (1986). Handbook of Cane engineering, third edition, Elsevier Science Publishers, New York, April 1986, p1070-1072.

Johnson Thompson Africa's Boiler Awareness \& maintenance course notes.

Mangwengwende S. E. Tariffs and subsidies in Zimbabwe's reforming electricity industry: steering a utility through turbulent times, Energy Policy (30) (2002) 947-958.

Nyatanga O (2002). ZESA Tariff Schedule for October 2002, utility company circular. Zimbabwe.

Renschhausen M. M (2001). Economic Analysis of Energy Systems, unpublished lecture notes.

Winrock International Institute for Agricultural Development (WIIAD) (1994). Energy from Sugar cane cogeneration in Honduras, Report No. 94-02, Washington DC.

Yunus A. C and Michael A. B. (1994).Thermodynamics: an Engineering Approach second Edition; McGraw Hill. New York, p55-62.

Doing business in the USA general information, www.marielandel.com/en/implanter txt.htm, viewed 22 June 2002.

Electricity import information, www.indexmundi.com $/ \mathrm{g} /$ g.aspx?c=zi\&v=83, viewed 23 April 2011.

Received 22 September 2010; revised 10 July 2011 